\title{
Strategies for Translating the Passive Structure in Scientific Discourse
}

\author{
Luu Trong Tuan \\ National University of Ho Chi Minh City \\ 140/67 Phan Van Tri Street, Ward 12, Binh Thanh District, Ho Chi Minh City, Vietnam \\ E-mail: luutrongtuan@hcm.fpt.vn
}

\begin{abstract}
The high frequency of passives in scientific writing is also substantiated by Celce-Murcia and Larsen-Freeman's (1983: 228) frequency continuum. It is their high frequency in scientific writing that renders passive structures unignorable for scientific translators as well as indispensible enough for this paper to revisit these constructions. From the perspectives on translating the passive structure from English to Vietnamese, strategies for translating the passive structure in scientific writing were proposed to guide scientific translators on how to translate the passive structure without actor, translate the English nominalizations following the verbs of experience, and translate the English passive structure in the relative clause of place as well as when to retain the actor in the translated text.
\end{abstract}

Keywords: Passive structure, Scientific writing, Theme-rheme structure, Nominalization, Source-oriented translation, Source-independent translation

\section{The passive structure at a glimpse}

In English and the other European languages, the passive voice is defined in terms of morphorlogy, syntax, and semantics. According to traditional descriptive grammar, the term "passive voice" refers to the placement of the object at the subject's position, together with the emergence of the passive morphemes (Radford 1981). Givón (1990: 566) portrays the subject function of non-agent roles in the passive sentences in contrast with roles of subjects in the active sentences via the subsequent illustration:

Active: (Actor) $>$ Beneficient $>$ Patient $>$ Other roles

Passive: Beneficient $>$ Patient $>$ Other roles

Keenan views the passive as "a common structure in the world languages" (1985: 243). The passive voice is not common in the spoken language unless the speaker wishes to highlight something. The written discourse, on the contrary, contains the stricter devices to link the clauses than those in the spoken utterance. The passive occasionally emerges in the discourse to deal with the need for linking clauses. Siewierska points out that the necessity for the use of the passive varies from language to language, hinging on internal linguistic features of the passive and available strategies to express the above functions (1984: 217-8). "The above functions" Siewierska refers to are topic identification, impersonalization and detransitivisation.

There are numerous reasons for the use of passive voice, the first of which is to serve topicalizing function. Givón contends that passivization is the process by which a non-agent gets promoted up to the subject of the sentence (1979: 186). Givón defines promotional passive voice as the structure where the subject of the passive structure goes through the complete promotion up to subjecthood. This type of structure tends to embrace the subsequent properties:

- enabling the agent of the passive voice to emerge optionally;

- coding the passive verb in the more stative and intransitive grammatical form; and

- confining the range of non-agent case-roles which can become the subject of the passive structure. (1990: 575)

In view of the cognitive framework, Rudzka-Ostyn lists specific parameters employed to analyze a particular situation: "vantage point, figure-ground alignment, levels of specificity/schematicity, backgrounding, foregrounding, and other parameters" (1993: 15). All these aspects need to be looked through in the analysis of the passive voice. Passive voice is used as a foregrounding device underscoring the participant that should be prominent in the readers' awareness of the reality the writer intends to convey. In the passive structure, the 
patient tends to have higher topicality than the agent, and the agent is exceedingly non-topical or demoted (Givón 1994: 9).

The passive is a marked structure. Givón contrasts the active with passive construction and notes that "(the) neutral, less presuppositional main, active, declarative, affirmative clause-type is also the most frequent in discourse" (1979: 50) as well as contends that a structure will be deemed as syntactically more intricate if it deviates from the common speech-processing strategies established by the norm (1979: 74). Thus, the author regards the active construction as a non-marked one, but the passive construction as a marked one, implying a certain degree of accentuation conveyed by the writer/speaker. As the writer/speaker desires to accentuate an element, he is prone to lay it in a prominent position in the sentence - the beginning of the sentence.

Celce-Murcia and Larsen-Freeman's (1983: 228) frequency continuum demonstrates that the highest frequency of passives is encountered in scientific writing, but the lowest frequency in spoken discourse.

Least number of passives

per number of words

conversation

fiction

\author{
Highest number of passives \\ per number of words \\ scientific \\ writing
}

A content analysis by Banks (1994) on 11 researches in the field of oceanography reveals that the frequency of the passive construction is $31 \%$. This finding advocates the contention that the passive construction is a feature of the scientific text due to its impersonal nature. In Banks's (1994) view, except for the type of adjectival passives, the passive structure is composed of copula and complement. In other words, the passive voice is chiefly a relational process in which past participle is the second participant of the process. Banks employs the term "relational process" in a sense that systemic functional linguistics does (see Berry 1975, Downing \& Locke 1992, Halliday 1994, Eggins 1994).

The impersonal nature of the scientific text renders cognitive process significant. By nature, the cognitive process requires conscious subject in the active form, a senser (Halliday 1994, Eggins 1994), or experiencer (Downing \& Locke 1992). Thus, to evade referring to personal agent, metaphors emerge in the active sentences:

(1) Figure 1a shows depths ...

(2) A redetermination of the slope ... would cast light on these problems.

A figure can not demonstrate anything. It is the scientist who uses the figure to show that to the audience. Similarly, the act of redetermination does not substantiate anything, but rather, the scientist illuminates the problems via a redetermination of the slope.

The passive structure is an expression of the cognitive process implying conscious subject and metaphorical grammar in Halliday's (1994) perspective.

\section{Perspectives on the passive structure in Vietnamese language}

The passive construction currently occurring in Vietnamese language like "Trong phản ứng kết hợp hạt nhân, năng lượng được sản sinh bởi sự kết hợp các nguyên tử” ("In the nuclear fusion, energy is produced by the combination of atoms"), as Clark (1971) claims, is the copying of the passive structure in French and English languages. Clark (1971) points out that the concept "passive" can not apply to Vietnamese language, but rather, Vietnamese language has submissive or adversative verbs which Alves (2001) addresses as affective verbs with their implications displayed in Table 1.

Alves maintains that "bị" and "được" in Vietnamese language can not be the morphemes of the passive, and are unequivalent to the morphemes of the passive in English language since "bị" and "được" can be pursued by transitive verbs, intransitive verbs, and even nouns, as encountered in the respective sentences: "Nó bị đánh." ("He was beaten.": "bị̣" is followed by a transitive verb "đánh"), "Nó bị ngã." ("He fell.”: "bị̣" is followed by an intransitive verb "ngã"), and "Nó được điểm tốt." ("He got a good mark.": “được" is followed by a noun). In contrast, merely transitive verbs can involve in the English passive constructions. Furthermore, whereas the morphemes of the English passive carry the neutral implication, "bị" and "được" in Vietnamese language convey the negative and positive implications respectively. Sharing this view with Alves, Nguyen (1977), Nguyen (1986), Nguyen (2000), and Cao (2001) claim that "bị" and "được" are not function words operating as the passive construction markers, but modality verbs or even predicate verbs. 
Nonetheless, if predicated on the perspective that in the passive construction, the beginning position of the beneficient or patient and the semantics of "receiving" outweight the passive morpheme, then both Clark and Alves did not "master" Vietnamese language as well as Thompson (1965), who contends that even though certain obscurity entails the existence of active/passive forms in Vietnamese language, the verb "bị " or "được" pursued by the descriptive complement builds the logical passive in Vietnamese language. Siding with Clark and Alves, Hoang (2002) does not view "bị" and "được" as the passive morphemes since both can emerge in two forms of transitivity (see Figure 1):

Examples: 1) Nó bị ngã (He fell) (inwards)

2) Nó bị mất một chiếc ô trắng (He lost a white umbrella)

(outwards/active)

3) Nó bị tôi đánh (He got beaten by me) (outwards/passive)

Hoang (2002), however, acknowledges the passive function of "bị” and "được", and distinguishes "bị” with "indesirable" implication from "được" with "desirable" implication. Keenan (1985: 257-261) alleges that, in the languages where periphrastic passive occurs, at least four types of verbs are employed as passive predicate markers: (1) verbs of being (such as be in English, byt' in Russian, and être in French), (2) verbs of reception (for instance, the passive with get in English), (3) verbs of motion (such as the verb gayee in Hindi), and (4) verbs of experience (such as "bị”/““được” in Vietnamese).

In a nutshell, Thompson's (1965) the logical passive is a generalization of the passive structure, not bound by the three criteria: the beginning position of the beneficient - the passive morpheme - the reception of external action.

\section{Perspectives on translating the passive structure from English to Vietnamese}

\subsection{Using two-layered theme-rheme structure}

Thompson's (1965) view on the passive in Vietnamese language is more manifestly portrayed via two-layered theme-rheme structure where rheme is descriptive complement Thompson refers to. The translated text "Các vi khuẩn và mô chết bị thực bào nuốt" from the source text "Bacteria and dead tissues are swallowed by phagocytes" illustrates the two-layered theme-rheme construction of the passive in Vietnamese language (see Figure 2).

The interesting thing Nguyen (1977: 208) explores in the Vietnamese passive is that in certain cases, the moving of the noun phrase functioning as an object to the position of the subject sufficiently marks the passive structure without the passive marker prowling about:

Active: $\begin{gathered}\text { Pha bưng mâm lên. (1) } \\ \text { Pha carries the tray. } \\ \text { NP1 }\end{gathered}$ V NP2
Passive: Lúc mâm cơm bưng lên. (2)
When the tray carries
NP2 $\mathrm{V}$

As Nguyen (1977) explains, in the structure (1), the coincidence of the actor and the subject indicates that the verb bung lên conveys the active implication. By contrast, the sentence (2), where the beneficient plays the role of the sentential subject, contains the passive implication. According to Nguyen (1977), the passive implication in the structure (2) is not confined to the verb, but disseminates through the whole sentence. This notion of the passive structure in Vietnamese language tends to interpret the growing trend in the ellipsis of verbs of experience "bị”/“được” in modern Vietnamese language (Nguyen 2001: 178).

Thus, the new trend to translate such a scientific text as "Protein found in urine to be more than 3.5 gm/day suggests the nephrotic syndrome." is to hide the passive markers "bị"/“được" and produce such a translation as "Lượng đạm tìm thấy trong nước tiểu lớn hơn 3.5 gam/ngày là dấu hiệu hội chứng thận hư".

The above analysis suggests the translation of the English passive structure into Vietnamese language can resort to two-layered theme-rheme structure (see Figure 3). 
The translated text "Lượng đạm tìm thấy trong nước tiểu lớn hơn 3.5 gam/ngày là dấu hiệu hội chứng thận hư" indicates that both the verb of experience and the actor are concealed. Verbs of experience "bị"/"được" don't simply take "an object", but also "an event" represented by a theme-rheme structure, so such a word-for-word translation of English passive construction into Vietnamese as "bị/được + verb + bởi (by) + actor" inverts the theme-rheme sequence and diminishes its readership.

Tran (2004: 296-297) points out that the second layer in the two-layered theme-rheme structure is the active structure inside the passive structure, and adds that the active structure lends itself to the introverted and subjective cognitive process (attached to the speaker) underlying Oriental culture whereas the passive structure corresponds to the extrovert and objective cognitive process (detached from the speaker) found in Western culture.

\subsection{Translating the nominalizations with passive implications}

Assuming no passive morphemes, nominalizations with passive implications can be translated in the same way as passive structures are. Table 2 displays the source-oriented translation and the source-independent translation of the nominalization "an intoxication of the nervous system by the exotoxin (tetanospasmin) of Clostridium tetani" carrying no passive morphemes, but passive implication.
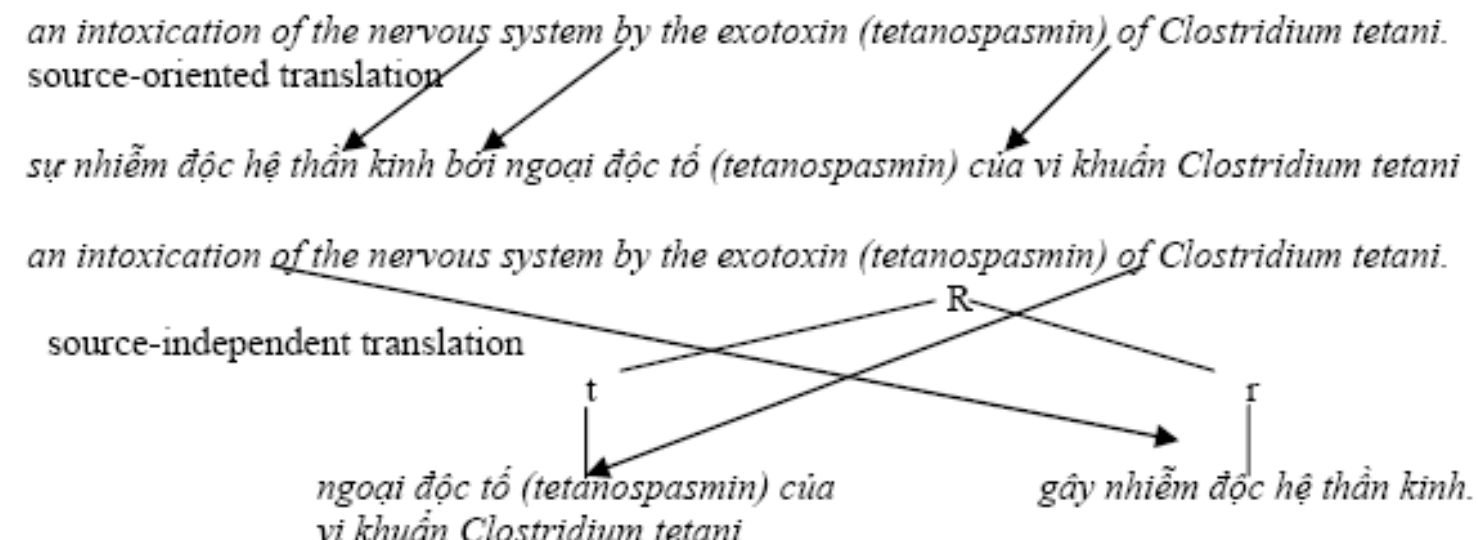

\subsection{Replacing the verb in passive form by a synonymous verb in active form}

The two-layered theme-rheme structure can not apply to all cases of translating English passive structure into Vietnamese. Another tactic is to supplant the verb in passive form with a synomous verb in active form. The translation "Hạt nhân, tạo bởi neutron và proton, nằm giữa nguyên tử và có các electron quay xung quanh" is the loan translation of the source text "The nucleus, which is composed of neutrons and protons, is in the middle of the atom and has electrons revolving around it"; however, the replacement of "is composed of" (passive construction) by "bao gồm" (meaning "consists of") (active construction) will produce source-independent translation "Hạt nhân, bao gồm neutron và proton, ..."

\subsection{Nominalizing the verb in the passive form}

In order to create source-independent translation, the passive construction can be decomposed and its verb gets nominalized. In the subsequent translation, the verb phrase is characterized by is converted into the noun phrase có đặc trung là (has such characteristics as) (see Table 3).

\subsection{Simulating the English passive construction (loan translation)}

In Nguyen's (2001: 176-178) view, language contact has brought new lexicons into Vietnamese language, and to some extent, influenced its syntax. The simulation of the English passive construction "bị/được ... bởi" ("passive morpheme ... by") as in the TV commercial "Chương trình này được tài trợ bởi ...." (This program is sponsored by ...) apparently creates a special effect attracting the audience's attention to the sponsor company's name, so this loan translation does not highlight the beneficient at the beginning of the sentence, but shifts the focus to the actor at the end. The calque of the English passive structure creates the wait time for the audience, and thereby, enhances their excitement on the path from the beneficient to the actor at the destination of the utterance.

This perspective is worth consideration and application. Nonetheless, even though the loan translation "bị/được ... bởi" ("passive morpheme ... by") produces certain special effects in some cases, it should not be abused, especially in scientific translation. Vietnamese culture is open, but highly selective. Notwithstanding a 
growing trend in the loan translation of English passive construction, the loan translation should be adapted. Contrast the two diachronic translations of the definition of "Nephrotic syndrome" (Table 4).

The current translation containing the loan translation of English passive construction "được đặc trưng bởi" makes the definition rather heavy, but if the passive marker "được" is deleted, its remainder "Hội chứng thận hư đặc trung bởi ..." sounds more harmonious and more tolerable in Vietnamese language.

\section{Strategies for translating the passive structure in scientific writing}

\subsection{Translating the passive structure without actor}

Upon translating the passive structure without the actor, the translator needs to explore if the discourse has advisability implication, or if there is any impact of intersentential theme-rheme string on the passive structure.

4.1.1 The passive structure has advisability implication

$$
\{\mathrm{N},(\text { be }+\mathrm{PP}(\mathrm{V}))\} \underset{\text { translate }}{\longrightarrow}\{\mathrm{V}, \mathrm{N}\} \text { (active) }
$$

where $\mathrm{N}$ refers to noun and $\mathrm{PP}(\mathrm{V})$ refers to past participle of the verb (see an illustration in Table 5).

Since impersonal sentences are a feature of the scientific texts, English passive structure with advisability implication should be translated as impersonal active structure to attain higher communicative quality in the translated text. This translation tactic should be employed especially for the passive structures with advisability implication highlighted in the source texts (see Table 6).

4.1.2 The passive structure is parallel to the active structure

When the passive structure is parallel to the active structure in the sentence, it tends to be translated as the active structure in the target language:

$$
\left.\left\{\left(\text { be }+\mathrm{PP}\left(\mathrm{V}_{1}\right)\right) \mathrm{AND} \mathrm{V}_{2}\right\} \underset{\text { translate }}{\longrightarrow} \text { active equivalent }\left(\mathrm{V}_{1}\right) \mathrm{VÀ} \mathrm{V}_{2}\right\}
$$

In the sentence in Table 7, the subject "Gastrointestinal discomfort and bleeding" is pursued by parallel predicates with "and" as the connector. Thus, if the first predicate is translated into the active structure: "Thường gặp rối loạn và xuất huyết tiêu hóa" (Often encounter gastrointestinal discomfort and bleeding), then "gastrointestinal discomfort and bleeding" has to be repeated in the translated text "và rối loạn và xuất huyết tiêu hóa có thể trầm trọng" (and gastrointestinal discomfort and bleeding may be severe). The parallelism in the source text may limit the effectiveness of the use of active structure to translate parallel predicates; however, the ellipsis of the passive marker "được" which reduces the loan transition into "thường gặp", instead of "thường được gặp" (be often encountered), as discussed in the section 3.1, appears to work. The translator can also translate the English passive structure as the active structure, as discussed in the section 3.3, with the replacement of "thường được gặp" (be often encountered) by its synonymous active verb "thường xảy ra" (often occur).

4.1.3 The passive structure is a ring of the theme-rheme chain

When the passive structure in the source text is a ring of the theme-rheme chain $\left\{\mathrm{T}_{1}, \mathrm{R}_{1} \rightarrow \mathrm{T}_{1}, \mathrm{R}_{2}\right.$ (passive) $\}$, its translation should retain the passive structure to sustain the theme-rheme chain:

$$
\left\{\mathrm{T}_{1}, \mathrm{R}_{1} \rightarrow \mathrm{T}_{1}, \mathrm{R}_{2} \text { (passive) }\right\} \underset{\text { translate }}{\longrightarrow}\left\{\mathrm{T}_{1}, \mathrm{R}_{1} \rightarrow \mathrm{T}_{1}, \mathrm{R}_{2} \text { (passive) }\right\}
$$

As displayed in Table 8, since the source text contains the parallel theme-rheme chain:

Aspirin và acetaminophen là các thuốc được chọn dùng. Các thuốc này nên dùng đều đặn ...

$\mathrm{T}_{1}$ T
$\mathrm{R}_{1}$

$$
\mathrm{T}_{2}=\mathrm{T}_{1}
$$

$\mathrm{R}_{2}$ 
the subject "Các thuốc này" (These drugs) in the second sentence should not be placed after the active verb "Nên dùng" (Please give), but rather, the translation of this sentence should retain the passive structure with the ellipsis of the passive marker "được": "Các thuốc này nên (được) dùng đều đặn ..."

\subsection{Retaining the actor in the translated text}

When the passive structure in the source text carries "by + agent", the translator needs to observe the semantic interaction between "agent" and the main verb of the sentence to explore if

- $\{$ Agent $=$ Doer of Verb $\}$ : the translation involves the use of two-layered theme-rheme structure as seen in an illustration presented in Table 9 (as discussed in the section 3.1).

However, in case the agent following by is a noun or noun phrase which is pursued by a relative clause, the translation should retain the passive structure (see Table 10).

- $\{$ Agent $=$ Medium of Verb $\}$ : "by + agent" then will be translated as $\{$ ởqua + môi trường $\}$ (in/through + medium)

"By" in the the structure "by + agent" should not be always translated as bơii, especially when it manifests itself in the scientific text, but rather, the translations "chuyển hóa $o$ ’ gan, và bài tiết qua thận" (metabolized in the liver, and excreted through the kidneys) are more common as illustrated in the subsequent example:

\begin{tabular}{|l|l|l|}
\hline \multicolumn{1}{|c|}{ Source text } & $\begin{array}{l}\text { Source-oriented translation } \\
\text { (loan translation) }\end{array}$ & Source-independent translation \\
\hline $\begin{array}{l}\text { Circulating salicylates are } 80 \% \\
\text { bound to plasma proteins, } \\
\text { metabolized by the liver, and } \\
\text { excreted by the kidneys. }\end{array}$ & $\begin{array}{l}80 \% \text { salicylate lưu hành gắn kết } \\
\text { với protein huyết tương, được } \\
\text { chuyển hóa bới gan, và bài tiết } \\
\text { bởi thận. }\end{array}$ & $\begin{array}{l}80 \% \text { salicylate lưu hành gắn kết } \\
\text { với protein huyết tương, được } \\
\text { chuyển hóa ơ gan, và bài tiết qua } \\
\text { thận. }\end{array}$ \\
\hline
\end{tabular}

\subsection{Translating the English nominalization as the passive structure in the target language}

Nominalizations that pursue verbs of experience should be translated as the passive structures of the verbs from those nominalizations:

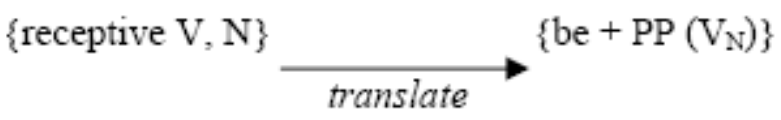

where:

$$
\mathrm{V}_{\mathrm{N}} \text { : verb from the nominonalization } \mathrm{N}
$$

As displayed in Table 11, the nominalization "oxidation" in the active structure "undergo oxidation" where "undergo" is a verb of experience should be translated as the passive structure of the verb from that nominalization. In this case, the passive marker "bị" is employed due to the negative semantics underlying the phenomenon of converting benzodiazepines into active metabolites in the liver. Similarly, "undergo hepatic metabolism" in the subsequent sentence is translated as the passive structure, but in this case, the passive marker "được" is resorted to due to the neutral semantics of the phrase "hepatic metabolism" (see Table 12).

\subsection{Translating the English passive structure in the relative clause of place as the nominalization}

The passive structure in the relative clause of place tends to be translated as the nominalization (see an illustration in Table 13):

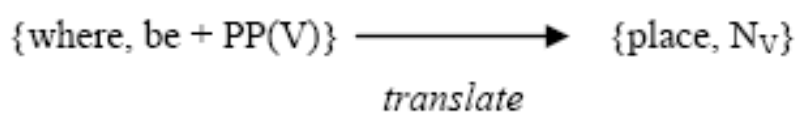

where:

$\mathrm{N}_{\mathrm{V}}$ : nominalization of the verb $\mathrm{V}$ 


\section{Concluding remarks}

"The passive voice is weak and colorless. It is also wordier than the active voice, and tends to hedge. Nevertheless, it is often used in technical writing because it promotes impersonality and restraint ..." (Turner 1971: 53). This high frequency of passives in scientific writing is also substantiated by Celce-Murcia and Larsen-Freeman's (1983: 228) frequency continuum. It is their high frequency in scientific writing that renders passive structures unignorable for scientific translators as well as indispensible enough for this paper to revisit these constructions. In Thompson's (1965) view, even though certain obscurity entails the existence of active/passive forms in Vietnamese language, the verb "bị" or "được" pursued by the descriptive complement builds the logical passive in Vietnamese language. From the perspectives on translating the passive structure from English to Vietnamese, strategies for translating the passive structure in scientific writing were proposed to guide scientific translators on how to translate the passive structure without actor, translate the English nominalizations following the verbs of experience, and translate the English passive structure in the relative clause of place as well as when to retain the actor in the translated text.

\section{References}

Alves, M.J. (2001). Distributional properties of causative verbs in some Mon-Khmer languages. Mon Khmer Studies: a Journal of Southeast Asian Linguistics and Languages 31, pp. 107-20.

Berry, M. (1975). Introduction to systemic linguistics. Vol. 1, Structures and systems. London: Batsford.

Cao, X.H. (2001). Addition and subtraction in linguistics. Journal of Linguistics, No. 10.

Celce-Murcia, M. \& D. Larsen-Freeman. (1983). The Grammar Book: An ESL/EFL Teacher's Course. Rowley, Mass.: Newbury House.

Clark, M. (1971). Passive and Ergative in Vietnamese. Working Papers in Linguistics, 3.8, 103-117. Honolulu, HI: Department of Linguistics, University of Hawaii at Manoa.

Downing, A. \& Locke, P. (1992). A university course in English grammar. Hemel Hempstead: Prentice Hall International.

Dunagan, W.C., \& Ridner, M.L. (1989). Manual of Medical Therapeutics. Washington: Department of Medicine, Washington University.

Eggins, S. (1994). An introduction to systemic functional linguistics. London: Pinter.

Givón, T. (1979). On Understanding Grammar. New York: Academic Press.

Givón, T. (1990). Syntax: A functional-typological introduction, Vol. II. Amsterdam: John Benjamins.

Givón, T. (1994). The pragmatics of de-transitive voice: Functional and typological aspects of inversion. In T.

Givón (ed.) Voice and Inversion. Amsterdam: John Benjamins. 3-44.

Halliday, M.A.K. (1994). An Introduction to Functional Grammar. London: Edward Arnold.

Hoang, V.V. (2002). Ngũ pháp kinh nghiệm của cú tiếng Việt - Mô tả theo quan điểm chức năng hệ thống (Empirical grammar of Vietnamese phrases - described according to systemic functional perspective). Hanoi: Social Science Publishing House.

Keenan, E.L. (1985). Passive in the world's languages. In T. Shopen (ed.) Language Typology and Syntactic Description. Vol. I Cambridge: Cambridge University Press.

Nguyen, K.T. (1977). Động tù trong tiếng Việt (Verbs in Vietnamese language). Hanoi: Social Science Publishing House.

Nguyen, M.T. (1986). Vai trò của "đuợc", "bị” trong câu bị động tiếng Việt (Roles of "được" and "bị” in Vietnamese passive sentences). Hanoi: Institute of Linguistics.

Nguyen, T.A. (2000). Tiếng Việt có thái bị động không? (Does Vietnamese language have passive form?). Journal of Linguistics, No. 5.

Nguyen, T.N.H. (2001). In Bui, K.T. (ed), Mấy vấn đề về tiếng Việt hiện đại (Some issues on modern Vietnamese language). Ho Chi Minh City: National University Press.

Radford, A. (1981). Transformational Syntax: A Student's Guide to Chomsky's Extended Standard Theory. New York: Cambridge University Press.

Rudzka-Ostyn, B. (1993). Introduction. In R.A. Geiger \& B. Rudzka-Ostyn (eds.) Conceptualizations and Mental Processing in Language, 1-20. 
Siewierska, A. (1984). The Passive: A Comparative Linguistic Analysis. London: Croom Helm.

Thompson, L. (1965). A Vietnamese Grammar. Seattle: University of Washington Press.

Tran, N.T. (2004). Tìm về bản sắc văn hóa Việt Nam (Discovering the identity of Vietnamese culture (4 $\left.4^{\text {th }} \mathrm{ed}\right)$. Ho Chi Minh City: Ho Chi Minh City Publishing House.

Turner, R.P. (1971). Grammar Review for Technical Writers (rev. ed). San Francisco: Rinehart.

Table 1. Submissive verbs in Vietnamese language and their implications

\begin{tabular}{|c|l|}
\hline Submissive verbs in Vietnamese language & Their implications \\
\hline bị & adversely affected \\
\hline được & favorably affected \\
\hline
\end{tabular}

Table 2. Translating the nominalizations with passive implications

\begin{tabular}{|c|c|c|}
\hline Source text & $\begin{array}{l}\text { Source-oriented translation } \\
\text { (word-for-word translation) }\end{array}$ & Source-independent translation \\
\hline $\begin{array}{l}\text { Tetanus is characterized by } \\
\text { generalized (occasionally } \\
\text { localized) muscle spasm resulting } \\
\text { from an intoxication of the } \\
\text { nervous system by the exotoxin } \\
\text { (tetanospasmin) of Clostridium } \\
\text { tetani. }\end{array}$ & $\begin{array}{l}\text { Bệnh uốn ván có đặc trưng là co } \\
\text { giật cơ toàn thân (có khi co giật } \\
\text { khu trú), do sư nhiếm độc hệ thần } \\
\text { kinh bới ngoại độc tố } \\
\text { (tetanospasmin) của vi khuẩn } \\
\text { Clostridium tetani }\end{array}$ & $\begin{array}{l}\text { Bệnh uốn ván có đặc trưng là co } \\
\text { giật cơ toàn thân (có khi co giật } \\
\text { khu trú), do ngoại độc tố } \\
\text { (tetanospasmin) cúa vi khuẩn } \\
\text { Clostridium tetani gây nhiếm độc } \\
\text { hệ thần kinh. }\end{array}$ \\
\hline
\end{tabular}

Table 3. Nominalizing the verb in the passive form

Tetanus is characterized by generalized (occasionally localized) muscle spasm resulting from an intoxication of the nervous system by the exotoxin (tetanospasmin) of Clostridium tetani.
Bệnh uốn ván có đặc trung là co giật cơ toàn thân (có khi co giật khu trú), do ngoại độc tố (tetanospasmin) của vi khuẩn Clostridium tetani gây nhiễm độc hệ thần kinh.

Table 4. The two diachronic translations of the definition of "Nephrotic syndrome

\begin{tabular}{|c|c|}
\hline Old translation & Current translation \\
\hline $\begin{array}{l}\text { Hội chứng thận hư là danh tù để chỉ tình trạng tiểu } \\
\text { đạm hơn } 3,5 \mathrm{~g} / \mathrm{ngày} . . . \\
\text { (Nephrotic syndrome is the term denoting } \\
\text { proteinuria of more than } 3.5 \mathrm{~g} \text { per day) }\end{array}$ & $\begin{array}{l}\text { Hội chứng thận hư đurọc đặc trung bởi tiểu đạm hơn } \\
3,5 \mathrm{~g} / \text { ngày ... } \\
\text { (Nephrotic syndrome is characterized by proteinuria } \\
\text { of more than } 3.5 \mathrm{~g} \text { per day) }\end{array}$ \\
\hline
\end{tabular}

Table 5. An illustration of translating the passive structure with advisability implication

\begin{tabular}{|l|l|l|}
\hline \multicolumn{1}{|c|}{ Source text } & \multicolumn{1}{|c|}{ Source-oriented translation } & \multicolumn{1}{c|}{ Source-independent translation } \\
\hline $\begin{array}{l}\text { Fever should not be treated until } \\
\text { the cause is considered. }\end{array}$ & $\begin{array}{l}\text { Sốt không nên được điều trị cho } \\
\text { đến khi nguyên nhân được xác } \\
\text { dịnh. }\end{array}$ & $\begin{array}{l}\text { Không nên điều trị sốt cho đến } \\
\text { khi đạnh đuợc nguyên nhân. }\end{array}$ \\
\hline
\end{tabular}


Table 6. Translating the passive structure with advisability implication using impersonal active structure

\begin{tabular}{|c|c|c|}
\hline Source text & Source-oriented translation & $\begin{array}{l}\text { Source-independent translation } \\
\text { (using impersonal active structure } \\
\text { as highlighted) }\end{array}$ \\
\hline $\begin{array}{l}\text { Therefore, aspirin should be } \\
\text { avoided in patients with bleeding } \\
\text { disorders, severe liver or renal } \\
\text { disease, and particularly in } \\
\text { patients taking warfarin or } \\
\text { corticosteroids. } \\
\text { (bold as in original) }\end{array}$ & $\begin{array}{l}\text { Do đó, aspirin nên tránh sử } \\
\text { dụng ở những bệnh nhân có rối } \\
\text { loạn chảy máu, bệnh gan hay thận } \\
\text { nặng, và nhất là ở bệnh nhân } \\
\text { đang dùng warfarin hay } \\
\text { corticosteroid. }\end{array}$ & $\begin{array}{l}\text { Do đó, nên tránh sử dụng } \\
\text { aspirin ở những bệnh nhân có rối } \\
\text { loạn chảy máu, bẹ̣nh gan hay thận } \\
\text { nặng, và nhất là ở bệnh nhân } \\
\text { đang dùng warfarin hay } \\
\text { corticosteroid. }\end{array}$ \\
\hline
\end{tabular}

[Source: Dunagan, W.C., \& Ridner, M.L. (1989)]

Table 7. An illustration of translating the passive structure parallel to the active structure

\begin{tabular}{|l|l|l|}
\hline \multicolumn{1}{|c|}{ Source text } & \multicolumn{1}{|c|}{ Source-oriented translation } & \multicolumn{1}{|c|}{ Source-independent translation } \\
\hline $\begin{array}{l}\text { Gastrointestinal discomfort and } \\
\text { bleeding are often encountered } \\
\text { and may be severe. }\end{array}$ & $\begin{array}{l}\text { Rối loạn và xuất huyết tiêu hóa } \\
\text { thuờng được gặp và có thể trầm } \\
\text { trọng. }\end{array}$ & $\begin{array}{l}\text { Rối loạn và xuất huyết tiêu hóa } \\
\text { thuờng xảy ra và có thể trầm } \\
\text { trọng. }\end{array}$ \\
\hline
\end{tabular}

Table 8. An illustration of translating the passive structure as a ring of the theme-rheme chain

\begin{tabular}{|c|c|c|}
\hline Source text & Using the active structure & Using the passive structure \\
\hline $\begin{array}{l}\text { Aspirin and acetaminophen are } \\
\text { the drugs of choice. } \\
\text { These drugs should be given } \\
\text { regularly ( } 325-650 \mathrm{mg} \text { q3-4h) } \\
\text { until the underlying disease } \\
\text { process has been controlled. }\end{array}$ & $\begin{array}{l}\text { Aspirin và acetaminophen là các } \\
\text { thuốc được chọn dùng. Nên dùng } \\
\text { các thuốc này đều đặn (325-650 } \\
\text { mg mối 3-4 giờ) cho đến khi } \\
\text { kiểm soát được tiến triển của } \\
\text { bệnh nền. }\end{array}$ & $\begin{array}{l}\text { Aspirin và acetaminophen là các } \\
\text { thuốc được chọn dùng. Các thuốc } \\
\text { này nên dùng đều đặn (325-650 } \\
\text { mg mối 3-4 giờ) cho đến khi } \\
\text { kiểm soát được tiến triển của } \\
\text { bệnh nền. }\end{array}$ \\
\hline
\end{tabular}

Table 9. An illustration of translating the passive structure with agent as doer of verb

\begin{tabular}{|l|l|l|}
\hline \multicolumn{1}{|c|}{ Source text } & \multicolumn{1}{|c|}{$\begin{array}{c}\text { Source-oriented translation } \\
\text { (loan translation) }\end{array}$} & $\begin{array}{c}\text { Source-independent translation } \\
\text { (using two-layered theme-rheme } \\
\text { structure) }\end{array}$ \\
\hline $\begin{array}{l}\text { The patient's report of pain must } \\
\text { be accepted by the physician. }\end{array}$ & $\begin{array}{l}\text { Cơn đau bệnh nhân khai phải } \\
\text { được ghi nhận bởi thầy thuốc. }\end{array}$ & $\begin{array}{l}\text { Cơn đau bệnh nhân khai phải } \\
\text { được thầy thuốc ghi nhận. }\end{array}$ \\
\hline
\end{tabular}

Table 10. An illustration of translating the passive structure with agent as doer of verb pursued by a relative clause

\begin{tabular}{|l|l|l|}
\hline \multicolumn{1}{|c|}{ Source text } & \multicolumn{1}{|c|}{$\begin{array}{c}\text { Using two-layered theme-rheme } \\
\text { structure }\end{array}$} & \multicolumn{1}{|c|}{ Retaining "by + agent" } \\
\hline $\begin{array}{l}\text { Thermoreceptive nociceptors } \\
\text { are stimulated by temperatures } \\
\text { that are potentially tissue } \\
\text { damaging. }\end{array}$ & $\begin{array}{l}\text { Thể tiếp nhận thống nhiệt do mức } \\
\text { nhiệt độ có thể gây tổn thương mô } \\
\text { kich thich. }\end{array}$ & $\begin{array}{l}\text { Thể tiếp nhận thống nhiệt bị kich } \\
\text { thich bởi mức nhiệt độ có thể gây } \\
\text { tổn thương mô. }\end{array}$ \\
\hline
\end{tabular}


Table 11. An illustration of translating the English nominalization as the passive structure in the target language

\begin{tabular}{|c|c|c|}
\hline Source text & $\begin{array}{l}\text { Source-oriented translation } \\
\text { (loan translation) }\end{array}$ & Source-independent translation \\
\hline $\begin{array}{l}\text { Most benzodiazepines undergo } \\
\text { oxidation to active metabolites in } \\
\text { the liver. }\end{array}$ & $\begin{array}{l}\text { Đa số các thuốc benzodiazepine } \\
\text { trải qua sự oxy hóa chuyển thành } \\
\text { chất chuyển hóa hoạt động tại } \\
\text { gan. }\end{array}$ & $\begin{array}{l}\text { Đa số các thuốc benzodiazepine } \\
\text { bị ôxy hóa thành chất chuyển hóa } \\
\text { hoạt động tại gan. }\end{array}$ \\
\hline
\end{tabular}

Table 12. An illustration of translating the neutral English nominalization as the passive structure in the target language using the passive marker "được"

\begin{tabular}{|l|l|l|}
\hline \multicolumn{1}{|c|}{ Source text } & \multicolumn{1}{|c|}{$\begin{array}{c}\text { Source-oriented translation } \\
\text { (loan translation) }\end{array}$} & Source-independent translation \\
\hline $\begin{array}{l}\text { Although all of these compounds } \\
\text { undergo hepatic metabolism, } \\
\text { individual patients differ } \\
\text { significantly in their metabolism of } \\
\text { these drugs. }\end{array}$ & $\begin{array}{l}\text { Mặc dù tất cả các thuốc này đều } \\
\text { trái qua sự chuyển hóa ở gan, } \\
\text { nhưng chuyển hóa rất khác biệt } \\
\text { tùy từng bệnh nhân. }\end{array}$ & $\begin{array}{l}\text { Mặc dù tất cả các thuốc này đều } \\
\text { đuợển hóa ở gan, nhưng } \\
\text { chuê̂n hóa rất khác biệt tùy } \\
\text { từng bệnh nhân. }\end{array}$ \\
\hline
\end{tabular}

Table 13. An illustration of translating the English passive structure in the relative clause of place as the nominalization

\begin{tabular}{|c|c|c|}
\hline Source text & $\begin{array}{l}\text { Source-oriented translation } \\
\text { (loan translation) }\end{array}$ & Source-independent translation \\
\hline $\begin{array}{l}\text { If an injected drug like penicillin } \\
\text { is not absorbed, it stays where it } \\
\text { was injected and may cause } \\
\text { enough irritation to generate a } \\
\text { sterile abscess. }\end{array}$ & $\begin{array}{l}\text { Nếu một loại thuốc tiêm như } \\
\text { penicillin không được hấp thu, thì } \\
\text { nó sẽ nằm nguyên nơi nó được } \\
\text { tiêm và có thể gây kích thích đến } \\
\text { mức sinh ra áp xe vô trùng. }\end{array}$ & $\begin{array}{l}\text { Nếu một loại thuốc tiêm như } \\
\text { penicillin không được hấp thu, thì } \\
\text { nó sẽ nằm nguyên nơ tiêm chich } \\
\text { và có thể gây kích thích đến mức } \\
\text { sinh ra áp xe vô trùng. }\end{array}$ \\
\hline
\end{tabular}

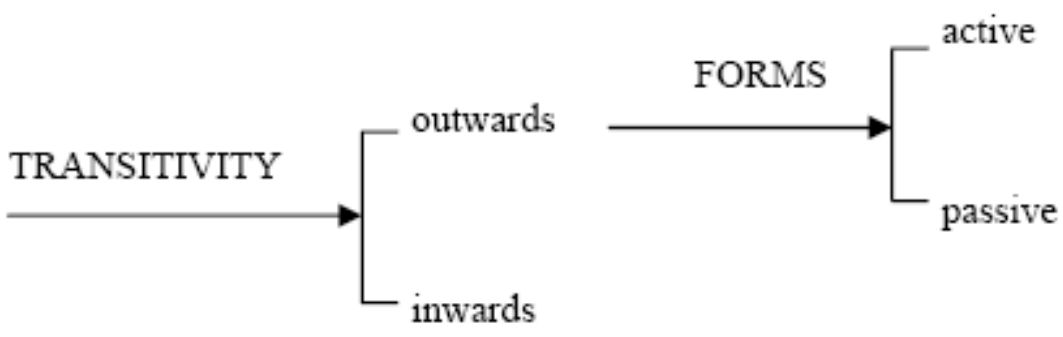

Figure 1. "Bị" and "được" in two forms of transitivity 


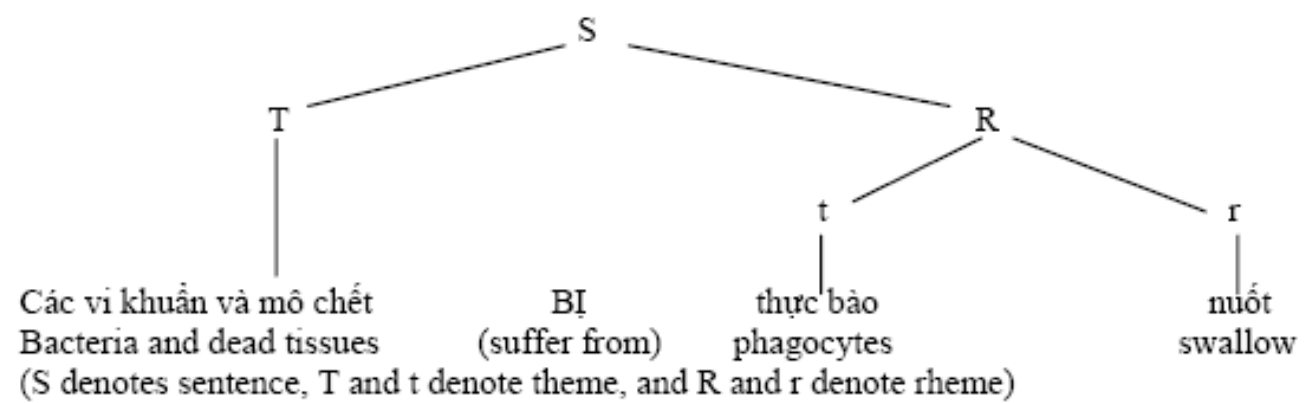

Figure 2. The two-layered theme-rheme construction of the passive in Vietnamese language

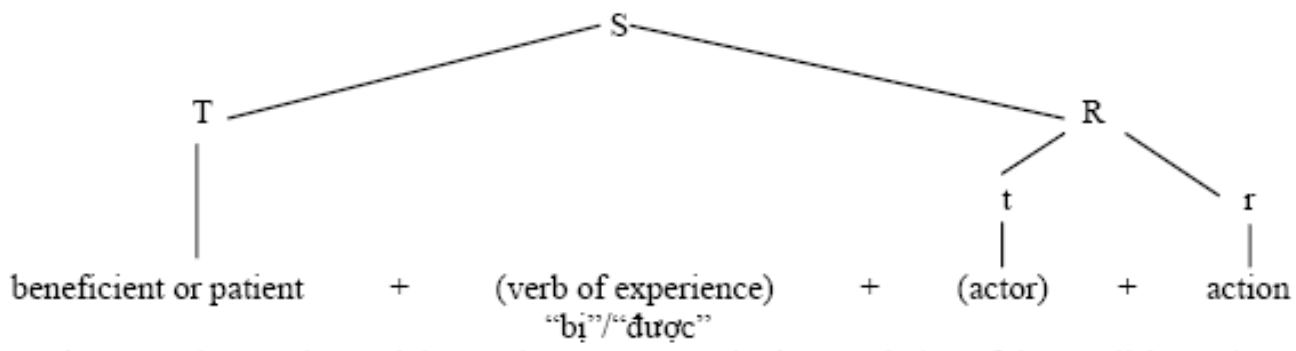

Figure 3. The two-layered theme-rheme structure in the translation of the English passive structure into Vietnamese language 